\title{
Impact of Innovation on Organisational Management: the Case of University of Lagos
}

\author{
S. C. Madumere ${ }^{1}$ \\ ${ }^{1}$ University of Lagos [E-mail: drmadumere@yahoo.com]
}

\begin{abstract}
This study examined whether organisational change, including restructuring of top leadership, is related to the effectiveness of organisational management. Data were collected from a sample of 177 participants, including students (120); senior members of staff (made up of 24 lecturers, 21 administrative staff) and Heads of Departments (12). These were drawn from the nine faculties in the University of Lagos, Akoka. The results were that organisational changes could occur without affecting organisational effectiveness. The study also found that University of Lagos is dynamic, notwithstanding the facilities or persons that change may affect.
\end{abstract}

Keywords: Innovation management; Organisational development; Restructuring

\section{$1 \quad$ Introduction}

For effective management of any organisation, innovation is expected to bring about a high degree of autonomy that enables it achieve its goal (Gbolahan and Moruf 1997; Utomi 1998; Albert 2000). In this study, innovation is seen as a necessary ingredient of effectiveness in any democratic setting. Nadler in Moruf and Gbolahan (1997); Kolades (1998) and Ehie (1999) agree that innovation is of three types. The first is technological, the second is structural and the third is organisational. Decision-making and policy implementation are said to be influenced by certain models of innovation. These include: social interaction model (S-I) by Miles (1994) and Mubert (1996); Research Development and Diffusion Model (RD\&D) by Benis and Lawler (1994); and Problem solving model (P-S) by Havelock and Skinner (1997).

In the case of university management, the three models of change are relevant. This is because even if its goal is clear (i.e. academic excellence (Madumere, 1999)), university management is complex and involves a high 
degree of inquisitiveness in all aspects of goal achievement. While endorsing the view that innovation is in line with organisational effectiveness, it is important to note that unnecessary change could be disastrous to goal attainment (Porras \& Hoffer 1986; and Schein 1988). When the innovation or change is in the negative, the desired effectiveness is in question (Hicks and Zmud 2004).

Organisational management refers to formal institutions and the manner in which they are governed and controlled to achieve their goals. Innovation is seen here as change or a change process and introduction of new things, like new infrastructural facilities in an organisation. Innovations or changes in institutions or in the formal settings are not easily taken and accepted by the core elements. The core elements here refer to the personnel or the workforce in an organisation.

In the University of Lagos which is taken as a test case for this study, it is noted that various types of innovations occur, varying from change of personnel as when one of its Vice Chancellors was removed, to change of things in concept and also in structure or re-arrangement of things. The innovation could also affect the attitudes, expectations, skills, perceptions and knowledge of persons involved. In the case of universities, the organisational effectiveness is seen in terms of academic excellence. Creativity leads to innovation, which leads to new development and which gives the potential for increased growth (cf. Figure 1).

The introduction of new machines and other inputs or facilities like computers bring about tremendous positive changes in facilitation of management. On the other hand, employment of new qualified and experienced people improves the organisation, leading to further innovations, developments and the needed academic excellence (provided that the students are interested and that they are properly exposed to the new changes). Thus, it may be argued that creativity, innovation and organisational effectiveness are therefore related (Sharp \& Paisan 2000). Notwithstanding, incessant changes especially of the headship may be disastrous to goal attainment. Therefore, the impact of innovation on organisational management is worth studying to determine growth and further development. In the case of higher education institutions, it is also necessitated to determine the impact of change on higher institutions.

\section{Conceptual Framework and Knowledge Gap}

The theory of innovation and organisational effectiveness touches the growth and development of management (Hicks and Zmud 2004). Growth and development are separate and distinctive in some respects. However, every 
organisation needs them for its sustainability (Zmud, 2001). Growth is to do with increase in the size of an organisation's management and in the volume of its turnover. On the other hand, development is an innovation to do with expansion in objectives and structural relationships. Without development, members of an organisation may not be motivated to give their creativity and professional best (Adefisoye and Auinla 2004). It creates the potential for new growth and, as growth reaches the limits imposed by the existing stage of development, pressures often occur for further developments. Innovations lead to higher stages of development and new growth potentials, which results into organisational effectiveness (see Figure 1).

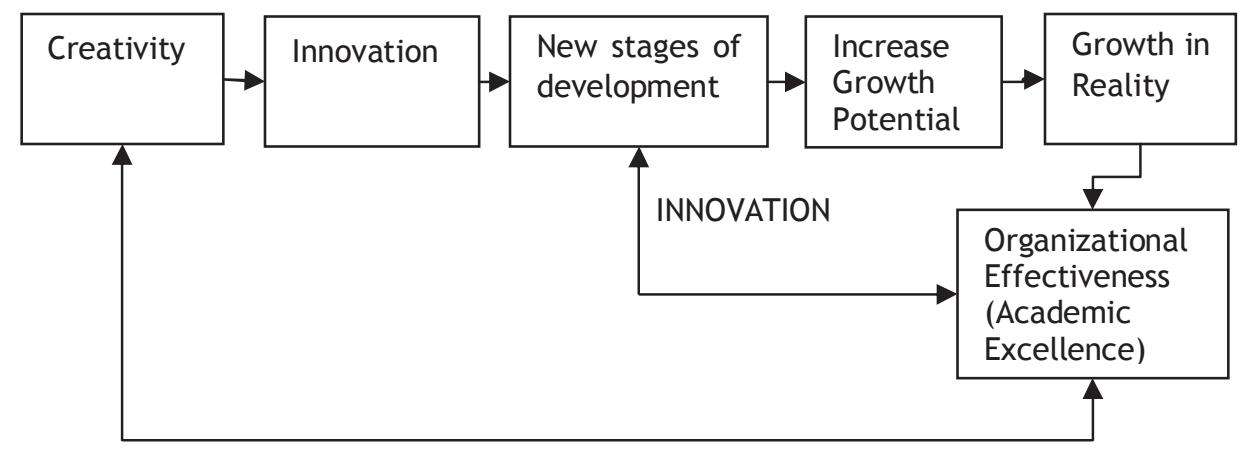

Figure 1: Growth and Development through Innovation

Figure 1 shows the way academic excellence results from creativity, innovation and processes of development and how these enhance the effectiveness of organisations. The objective of this study was to investigate the impact of innovation or change on organisational management, taking the case of University of Lagos, Akoka. The central problem to this study is: how does innovation impact organisational management? How will change bring about better management to maintain academic excellence for which the universities are aimed at? Lack of documented data on the effect of innovations on university organisational management poses the problem of repeating the same mistakes of the past management. The results of the study might assist in this regard. Presently the universities in Nigeria cannot be said to be paying their staff adequately. Organisational effectiveness is also tied with the level of salary of its workforce in a competitive market economy (Alos 2000). Hence the question of whether there is a remedy to poor staff remuneration. Moreover, Alos and Collier (2000) were of the opinion that; for an effective improvement of the quality of education in any learning institution, the teachers must be properly remunerated. Thus, the study undertook to respond to the following research questions: 1) is there significant relationship between innovation and organisational management and effectiveness? 2) Are staffs' attitudes 
significantly related to organisational change in Vice Chancellorship? 3) Are staffs' attitudes significantly related to change in the infrastructural facilities available at an institution? 4) What relationship exists between students' attitudes and changes in Vice Chancellorship and the infrastructural facilities for teaching and learning? The respective null hypothesis was that organisational change is not significantly related to organisational management and effectiveness.

\section{$3 \quad$ Method}

The study was carried out following a case study design. Data were collected from students, lecturers and administrative staff drawn from the nine faculties of the University of Lagos, Akoka. The distribution of these respondents is shown in Table 1.

Table 1: Sample of Respondents

\begin{tabular}{lcccc}
\hline Faculty & Students & $\begin{array}{c}\text { Academic } \\
\text { staff }\end{array}$ & $\begin{array}{c}\text { Heads of } \\
\text { Department }\end{array}$ & $\begin{array}{c}\text { Senior } \\
\text { Administrative Staff }\end{array}$ \\
\hline Education & 16 & 4 & 2 & 3 \\
Social Sciences & 12 & 2 & 1 & 2 \\
Arts & 12 & 2 & 1 & 2 \\
Law & 12 & 2 & 1 & 3 \\
Engineering & 15 & 2 & 2 & 2 \\
Physical Sciences & 13 & 3 & 1 & 2 \\
Business Admin. & 14 & 2 & 1 & 3 \\
Medicine & 12 & 4 & 2 & 2 \\
Architecture & 14 & 3 & 1 & 2 \\
Total & 120 & 24 & 12 & 21 \\
\hline
\end{tabular}

Questionnaires (reliability coefficient $=0.98$ ) were used to elicit the data. Multiple regression analysis and Pearson's Product Moment Correlation were used to analyse the data.

\section{$4 \quad$ Results}

The findings were that majority $(82 \%)$ of the respondents "disagreed" that organisational effectiveness of the institution is dependent on organisational innovations (Table 2). In the same way, the results indicate that $81 \%$ of the respondents disagreed that organisation changes are responsible for delay in 
student's graduation, or delays in salary, introduction of new infrastructures like machines and welfare packages.

Table 2: Perceptions of the Role of Innovation in the University's Development

\begin{tabular}{llll}
\hline Factor & Categories & Frequency & Percentage \\
\hline & Strongly disagree & 102 & 58 \\
The university organisation & Disagree & 43 & 24 \\
effectiveness is based on innovation & Undecided & 8 & 5 \\
in personnel and infrastructures & Agree & 14 & 8 \\
within the institution & Strongly agree & 10 & 6 \\
& Total & 177 & 100 \\
\hline \multirow{2}{*}{$\begin{array}{l}\text { Organisational changes or } \\
\text { innovations are responsible for }\end{array}$} & Strongly disagree & 100 & 58 \\
delays in graduation of students, & Disagree & 38 & 22 \\
distortion of university calendar, & Undecided & 10 & 6 \\
salary of staff and other welfare & Agree & 12 & 7 \\
packages & Strongly agree & 11 & 6 \\
& Total & 171 & 100 \\
\hline
\end{tabular}

The results of the hypothesis test are summarised in Table 3.

Table 3: Impact of Organisational Innovations on Management Effectiveness

\begin{tabular}{llllll}
\hline & $\begin{array}{l}\text { Sum of } \\
\text { squares }\end{array}$ & $\begin{array}{l}\text { Degrees of } \\
\text { freedom }\end{array}$ & $\begin{array}{l}\text { Mean } \\
\text { squares }\end{array}$ & F-ratio & Remarks \\
\hline Regression & 10321.94 & 2 & 56160.97 & 7.69 & .05 \\
Residual & 435734.69 & 647 & 670.38 & & \\
\hline
\end{tabular}

Multiple $\mathrm{R}=0.152 ; \mathrm{R}^{2}=0.023$

Adjusted $R^{2}=0.020 ;$ Standard Error $=25.891$

Calculated value $=3.40$

In Table 3, the hypothesis that organisational change is not significantly related to organisational management or its effectiveness is tested. The computed Fratio is 7.69, which is greater than the critical value of 3.02 at $\mathrm{P}=.05$ level of significance. Based on this the hypothesis is rejected. Organisational change can occur without affecting the institution's organisational effectiveness or management.

\section{Conclusions}

From the analysis presented, organisational management at the university of Lagos remains effective irrespective of whether a vice chancellor is changed or 
not. A change of the principal personnel of the university does not stop the lecturers and other staff members or the students from doing their work. Work goes on and all activities and salaries are not delayed due to change of personnel or infrastructure.

The university council, the National university Commission (NUC), the Senate and the Head of state as visitor to the university are responsible jointly for University management, and of course, the vice chancellor also, who acts as the immediate headship. The Vice-chancellor is accountable to the government and to the general public on what happens to the institution. His removal or change does not stop the system from working. To show however, that change is welcome at the university, a certain percentage of the respondents (13.5) agree that changes bring about effectiveness on the system (see table 2). Organisational changes are relevant in university management for facilitation of administration. Changes are not ruled out so long as they help to improve the system as when new machines or equipment are brought in to replace obsolete ones.

In conclusion, it could be emphatically stated that organisational changes or changes of personnel per say, do not hinder progress or cause delay in management in the university setting. Work goes on irrespective of change in staff or in infrastructure. The university does not however, jettison change but it sees change as one of the means of facilitating its management when new structures or infrastructures are purchased especially for replacement of obsolete ones.

\section{References}

Adefisoye, O. U. and Ayinla, A. K. (2004). The Impact of Distributed Data Processing System as Perceived by Provincial Users. Columbia: Information files.

Alos A. J. and Collier M. A. (2000). Reengineering the Corporation. New York: Harper Business.

Benis, W. G. and Lawler J. U. (1994). The planning of Change, New York, Holt, Rinehart and Winston, Inc.

Ehie, I. and Alos, A. I. (1999). Manufacturing Practices in Developing countries: Nigerian Experience Proceedings Decision Science Conference, Las Vegas.

Gbolahan G. and Moruf A. A. (1997). Organisational Behaviour. A basic introduction. Lagos: Pumark Nigeria Limited. 
Havelock and Skinner (1997). A Guide to innovation in education Centre for Research on Utilisation of knowledge (CRSK) Ann Arbour the University of Michigan.

Hicks, A. G., and Zmud R.W. (2004). The Implementation Process: A Change Approach, Ms Quarterly, Vol. 3, No. 2, 2004.

Kolades, C. (1998). Corporate Governance and Management Effectiveness". LBS Nigerian Management Review, Vol. 3, No. 1.

Madumere, S. C. (1999). Organisational Management and Theory. Ibilasami Publishers, Lagos.

Miles, M. B. (ed.) (1994). Innovation in Education N.Y. Teachers College Press, Columbia University.

Mubert, I. (1996). A Guide to Innovation in Education Centre for Research on Utilisation of Knowledge. The Michigan State University.

Nadler, D.A. (1987). The Effective Management of Organisational Behaviour. Englewood Cliffs. N.J. Prentice-Hall.

Porras, J. I. and S. J. Itoffer (1986). Common Behaviour changes in successful Organisation Development Efforts, Journal of Applied Behavioural Science. Vol. 2, No. 2.

Sharp and Paisan K. (2000). "That Working Culture". Doctoral Dissertation Sri Lanka University. 